\title{
Atmospheric greenhouse gases retrieved from SCIAMACHY: comparison to ground-based FTS measurements and model results
}

\author{
O. Schneising ${ }^{1}$, P. Bergamaschi ${ }^{2}$, H. Bovensmann ${ }^{1}$, M. Buchwitz ${ }^{1}$, J. P. Burrows ${ }^{1}$, N. M. Deutscher ${ }^{1,3}$, \\ D. W. T. Griffith ${ }^{3}$, J. Heymann ${ }^{1}$, R. Macatangay ${ }^{3}$, J. Messerschmidt ${ }^{4}$, J. Notholt ${ }^{1}$, M. Rettinger ${ }^{5}$, M. Reuter ${ }^{1}$, \\ R. Sussmann ${ }^{5}$, V. A. Velazco ${ }^{1}$, T. Warneke ${ }^{1}$, P. O. Wennberg ${ }^{4}$, and D. Wunch ${ }^{4}$ \\ ${ }^{1}$ Institute of Environmental Physics (IUP), University of Bremen FB1, Bremen, Germany \\ ${ }^{2}$ Institute for Environment and Sustainability (IES), European Commission Joint Research Centre (EC-JRC), Ispra, Italy \\ ${ }^{3}$ School of Chemistry, University of Wollongong, Wollongong, New South Wales, Australia \\ ${ }^{4}$ California Institute of Technology, Pasadena, California, USA \\ ${ }^{5}$ Institute for Meteorology and Climate Research (IMK-IFU), Garmisch-Partenkirchen, Germany
}

Correspondence to: O. Schneising (oliver.schneising @iup.physik.uni-bremen.de)

Received: 18 September 2011 - Published in Atmos. Chem. Phys. Discuss.: 26 October 2011

Revised: 27 January 2012 - Accepted: 30 January 2012 - Published: 9 February 2012

\begin{abstract}
SCIAMACHY onboard ENVISAT (launched in 2002) enables the retrieval of global long-term columnaveraged dry air mole fractions of the two most important anthropogenic greenhouse gases carbon dioxide and methane (denoted $\mathrm{XCO}_{2}$ and $\mathrm{XCH}_{4}$ ). In order to assess the quality of the greenhouse gas data obtained with the recently introduced $\mathrm{v} 2$ of the scientific retrieval algorithm WFM-DOAS, we present validations with ground-based Fourier Transform Spectrometer (FTS) measurements and comparisons with model results at eight Total Carbon Column Observing Network (TCCON) sites providing realistic error estimates of the satellite data. Such validation is a prerequisite to assess the suitability of data sets for their use in inverse modelling.
\end{abstract}

It is shown that there are generally no significant differences between the carbon dioxide annual increases of SCIAMACHY and the assimilation system CarbonTracker (2.00土 $0.16 \mathrm{ppm} \mathrm{yr}^{-1}$ compared to $1.94 \pm 0.03 \mathrm{ppm} \mathrm{yr}^{-1}$ on global average). The $\mathrm{XCO}_{2}$ seasonal cycle amplitudes derived from SCIAMACHY are typically larger than those from TCCON which are in turn larger than those from CarbonTracker. The absolute values of the northern hemispheric TCCON seasonal cycle amplitudes are closer to SCIAMACHY than to CarbonTracker and the corresponding differences are not significant when compared with SCIAMACHY, whereas they can be significant for a subset of the analysed TCCON sites when compared with CarbonTracker. At Darwin we find discrepancies of the seasonal cycle derived from SCIAMACHY compared to the other data sets which can probably be as- cribed to occurrences of undetected thin clouds. Based on the comparison with the reference data, we conclude that the carbon dioxide data set can be characterised by a regional relative precision (mean standard deviation of the differences) of about $2.2 \mathrm{ppm}$ and a relative accuracy (standard deviation of the mean differences) of 1.1-1.2 ppm for monthly average composites within a radius of $500 \mathrm{~km}$.

For methane, prior to November 2005, the regional relative precision amounts to $12 \mathrm{ppb}$ and the relative accuracy is about 3 ppb for monthly composite averages within the same radius. The loss of some spectral detector pixels results in a degradation of performance thereafter in the spectral range currently used for the methane column retrieval. This leads to larger scatter and lower $\mathrm{XCH}_{4}$ values are retrieved in the tropics for the subsequent time period degrading the relative accuracy. As a result, the overall relative precision is estimated to be $17 \mathrm{ppb}$ and the relative accuracy is in the range of about $10-20 \mathrm{ppb}$ for monthly averages within a radius of $500 \mathrm{~km}$.

The derived estimates show that the SCIAMACHY $\mathrm{XCH}_{4}$ data set before November 2005 is suitable for regional source/sink determination and regional-scale flux uncertainty reduction via inverse modelling worldwide. In addition, the $\mathrm{XCO}_{2}$ monthly data potentially provide valuable information in continental regions, where there is sparse sampling by surface flask measurements. 


\section{Introduction}

The increase in the atmospheric abundance of the two most important anthropogenic greenhouse gases carbon dioxide and methane since the start of the Industrial Revolution has been well documented by the Intergovernmental Panel on Climate Change (IPCC) (Solomon et al., 2007). Carbon dioxide levels have risen steadily, whereas atmospheric methane amounts were rather stable from roughly 1999 to 2006 (Dlugokencky et al., 2003; Bousquet et al., 2006) followed by a renewed methane growth since 2007 observed from surface measurements (Rigby et al., 2008; Dlugokencky et al., 2009). Despite their importance, there are still many gaps in our understanding of the sources and sinks of these greenhouse gases (Stephens et al., 2007) and their biogeochemical feedbacks and response in a changing climate, hampering reliable climate predictions. However, theoretical studies have shown that satellite measurements have the potential to significantly reduce surface flux uncertainties by deducing strength and spatiotemporal distribution of the sources and sinks via inverse modelling, if the satellite data are accurate and precise enough (Rayner and O'Brien, 2001; Houweling et al., 2004; Miller et al., 2007; Chevallier et al., 2007). The reduction of regional flux uncertainties requires high sensitivity to near-surface greenhouse gas concentration changes because the variability due to regional sources and sinks is largest in the lowest atmospheric layers. Upper tropospheric concentrations are already essentially zonal due to atmospheric mixing and are not sufficient to reduce regionalscale flux uncertainties significantly.

Currently, there are only two satellite instruments orbiting the Earth which enable the retrieval of the columnaveraged dry air mole fractions of atmospheric carbon dioxide $\left(\mathrm{XCO}_{2}\right)$ and methane $\left(\mathrm{XCH}_{4}\right)$ with significant sensitivity in the boundary layer. This is achieved by retrieving $\mathrm{XCO}_{2}$ and $\mathrm{XCH}_{4}$ from measurements of reflected solar radiation in the near-infrared/shortwave-infrared (NIR/SWIR) spectral region $(0.75-3 \mu \mathrm{m})$. These instruments are SCIAMACHY onboard ENVISAT (launched in 2002) and TANSO onboard GOSAT (launched in 2009) (Yokota et al., 2009), which yield measurements of the relevant absorption bands of both gases in this spectral range. OCO-2 (originally scheduled to be launched in 2013 but temporarily put on hold due to re-evaluation of launch vehicle options) (Crisp et al., 2004; Boesch et al., 2011) will be another satellite designed to observe atmospheric carbon dioxide in the same spectral region as SCIAMACHY and TANSO. CarbonSat (Bovensmann et al., 2010), which is one of two candidate Earth Explorer Opportunity Missions (EE-8, to be launched in 2018), and the CarbonSat Constellation shall also measure $\mathrm{XCO}_{2}$ and $\mathrm{XCH}_{4}$ in this spectral range. Despite the coarser spatial and spectral resolution of SCIAMACHY compared to TANSO or future OCO-2 and CarbonSat, it is playing a pioneering role in the relatively new area of greenhouse gas observations from space (Buchwitz et al., 2005a,b, 2006, 2007;
Schneising et al., 2008, 2009, 2011; Reuter et al., 2010, 2011; Houweling et al., 2005; Bösch et al., 2006; Barkley et al., 2006a,c,b, 2007; Frankenberg et al., 2005, 2006, 2008b,a, 2011) because it was the only satellite instrument measuring $\mathrm{XCO}_{2}$ and $\mathrm{XCH}_{4}$ with high sensitivity in the boundary layer within the time period 2002-2009 and is planned to continue its measurements at least until 2014. Therefore, accurate analyses of SCIAMACHY data are essential to initiate consistent long-term time series of carbon dioxide and methane observations from space. SCIAMACHY data have already been incorporated in the atmospheric modelling of methane emissions (Bergamaschi et al., 2007, 2009) and in the estimation of wetland emissions by calibrating a simple model based on correlation analyses (Bloom et al., 2010).

In this manuscript, the long-term global carbon dioxide and methane dry air column-averaged mole fraction data sets from SCIAMACHY derived using Weighting Function Modified DOAS (WFM-DOAS) version 2 (Schneising et al., 2011) are validated with ground-based Fourier Transform Spectrometer (FTS) measurements and compared to global model simulations (CarbonTracker $\mathrm{XCO}_{2}$ (Peters et al., 2007, 2010) and TM5-4DVAR $\mathrm{XCH}_{4}$ (Meirink et al., 2008; Bergamaschi et al., 2009, 2010)) being optimised by assimilating highly accurate surface measurements from the NOAA/ESRL network.

\section{Data sets}

The intercomparison is performed at the following TCCON ground sites: Białystok (Poland), Bremen (Germany), Orléans (France), Garmisch (Germany), Park Falls (USA), Lamont (USA), Darwin (Australia), and Wollongong (Australia). For each analysed TCCON site, time series are generated comprising SCIAMACHY, FTS, and model data providing the basis for the validation and intercomparison study. SCIAMACHY and model results are available for the entire analysed time period ranging from 2003 to 2009 , whereas TCCON data are only available for certain subperiods depending on site (Park Falls since 2004, Darwin since 2005, Bremen since 2007, Lamont and Wollongong since 2008, Białystok, Orléans, and Garmisch since 2009). For other available TCCON sites with potential temporal overlap with the SCIAMACHY data, namely Lauder (New Zealand), Tsukuba (Japan), and Izaña (Spain), there are too few WFMDOAS retrievals passing the quality filter for a statistically significant comparison in the immediate vicinity of these sites. SCIAMACHY measurements over ocean are filtered out because of the lower surface reflectance and therefore the SCIAMACHY signal-to-noise ratio is poorer near these TCCON sites. 


\subsection{SCIAMACHY}

The grating spectrometer SCIAMACHY (SCanning Imaging Absorption spectroMeter for Atmospheric CHartographY), which is a multinational (Germany, The Netherlands, Belgium) contribution to the European environmental satellite ENVISAT, measures reflected, backscattered and transmitted solar radiation at moderately high spectral resolution $(0.2-$ $1.4 \mathrm{~nm}$ ) in the spectral region from $214 \mathrm{~nm}$ to $2386 \mathrm{~nm}$ (Burrows et al., 1990, 1995; Burrows and Chance, 1991; Bovensmann et al., 1999).

ENVISAT was launched into a sun-synchronous orbit in descending node having an equator crossing time of 10:00 a.m. local time. SCIAMACHY's observation of greenhouse gas overtone absorptions in the nearinfrared/shortwave infrared (NIR/SWIR) solar backscattered spectrum yield the vertical columns of $\mathrm{CO}_{2}$ and $\mathrm{CH}_{4}$ with high sensitivity down to the Earth's surface (Buchwitz et al., 2005a). The instrument scans $\pm 32^{\circ}$ across track around the nadir direction resulting in a swath width of $960 \mathrm{~km}$ consisting of single measurements with a horizontal resolution of typically $60 \mathrm{~km}$ across track by $30 \mathrm{~km}$ along track each for the spectral regions used in this study.

The global long-term SCIAMACHY greenhouse gas results to be validated are obtained using v2 (v2.1 $\mathrm{XCO}_{2}$ and v2.0.2 $\mathrm{XCH}_{4}$ ) of the scientific retrieval algorithm WFMDOAS recently introduced in Schneising et al. (2011), which is based on a fast look-up table scheme. For the WFMDv2.1 $\mathrm{XCO}_{2}$ data an additional empirical correction as a function of the signed scan angle $\phi \in\left[-32^{\circ}, 32^{\circ}\right]$ is applied to resolve a spurious dependency of the retrieved single ground scene $\mathrm{XCO}_{2}$ on $\phi$ (for details, see Heymann et al., 2012):

$\mathrm{XCO}_{2}^{\mathrm{C}}(\phi)=\mathrm{XCO}_{2}-\frac{3 \mathrm{ppm}}{1000\left(^{\circ}\right)^{2}} \cdot\left(\phi+47.3^{\circ}\right)^{2}+7 \mathrm{ppm}$

The sign of the scan angle (minus corresponds to measurements east of the nadir position) can be derived from the relative azimuth angle stated in the WFM-DOAS product files.

The single ground scene measurement retrieval precision after this correction derived from the method of averaging daily standard deviations of the retrieved $\mathrm{XCO}_{2}$ at different locations distributed around the globe (Schneising et al., 2011) provides a consistent estimate of about $5.4 \mathrm{ppm}$, which corresponds approximately to $1.4 \%$. The corresponding estimate of the single measurement precision for WFMDv2.0.2 $\mathrm{XCH}_{4}$ amounts to about $30 \mathrm{ppb}$ before November 2005 (and $70 \mathrm{ppb}$ afterwards), which corresponds approximately to $1.7 \%$ (4\%). In November 2005, the impact of solar protons resulted in persistent random telegraph noise of the detector pixel measuring the strongest $\mathrm{CH}_{4}$ absorption in the Q-branch of the $2 \nu_{3}$ band around $1666 \mathrm{~nm}$.

For each TCCON site, monthly means with sufficient SCIAMACHY ground scenes passing the quality filter within $500 \mathrm{~km}$ around the site are used for the validation and intercomparison study.

\subsection{FTS}

TCCON is a network of ground-based Fourier Transform Spectrometers recording direct solar spectra in the nearinfrared/shortwave-infrared spectral region (Wunch et al., 2011a). From these spectra, accurate and precise columnaveraged abundances of $\mathrm{CO}_{2}$ and $\mathrm{CH}_{4}$ are retrieved from spectral windows around $1.6 \mu \mathrm{m}$ providing a validation resource for column-averaged satellite data. Because of the direct solar-viewing measurement method potential biases due to atmospheric scattering are minimised.

To ensure comparability, all TCCON sites use similar instrumentation (Bruker IFS 125/HR for all sites used in this study) and a common retrieval algorithm based on scaling a priori profiles by least-squares fitting. The $\mathrm{CO}_{2}$ a priori profiles are derived from an empirical model based on GLOBALVIEW in situ data and extended to the stratosphere using an age of air relationship (Andrews et al., 2001). The $\mathrm{CH}_{4}$ a priori profiles are based on ACE FTS satellite (Bernath et al., 2005) and MkIV FTS balloon measurements (Toon, 1991).

The TCCON data are calibrated using airborne in situ measurements applying single scaling factors for each species for all sites consistently (Washenfelder et al., 2006; Deutscher et al., 2010; Wunch et al., 2010, 2011a; Messerschmidt et al., 2011). For $\mathrm{XCO}_{2}$ an additional empirical airmass-dependent correction is applied before calibration to account for spectroscopic inadequacies. The single measurement precision is about $0.15 \%$ for $\mathrm{XCO}_{2}$ and $0.2 \%$ for $\mathrm{XCH}_{4}$ (Toon et al., 2009). The estimated accuracy derived from the slope of the calibration curves and the corresponding errors is about $0.8 \mathrm{ppm}$ for carbon dioxide and $7 \mathrm{ppb}$ for methane (2 $\sigma$, Wunch et al., 2010).

\subsection{CarbonTracker}

CarbonTracker developed by NOAA/ESRL in cooperation with many partners is a reanalysis of the recent global surface fluxes and the corresponding 3-D mole fractions of carbon dioxide estimated by assimilating highly accurate surface flask measurements from the NOAA/ESRL network and tall tower measurements using an Ensemble Kalman Filter technique (Peters et al., 2007, 2010). The underlying atmospheric transport model TM5 (Krol et al., 2005) with 25 vertical layers is driven by meteorological data from the European Centre for Medium Range Weather Forecasts (ECMWF). We use CarbonTracker with a horizontal resolution of $3^{\circ} \times 2^{\circ}$ and a temporal resolution of $3 \mathrm{~h}$. For the comparison, we employ the profiles of the recent CarbonTracker release 2010 which are temporally closest to the local overpass time of SCIAMACHY and integrate vertically to obtain the corresponding column-averaged mole fractions. 


\subsection{TM5-4DVAR}

The methane model simulations are based on the TM54DVAR inverse modelling system described in detail by Meirink et al. (2008), including subsequent further developments described by Bergamaschi et al. (2009, 2010). TM5 is an offline transport model (Krol et al., 2005), driven by meteorological fields from the ECMWF Integrated Forecast System (IFS) model. For the present study we apply the ERAINTERIM meteorological fields, a reanalysis of the period from 1989 until present, to ensure consistent meteorological fields over the time period analysed (2003-2009). We employ the standard TM5 version (TM5 cycle 1 ), with 25 vertical layers, and apply a horizontal resolution of $6^{\circ} \times 4^{\circ}$. The 4-dimensional variational (4DVAR) optimisation technique minimises iteratively a cost function taking into account an a priori estimate of the emissions, based on the emission inventories used in Bergamaschi et al. (2010). We assimilate only surface observations from the NOAA Earth System Research Laboratory (ESRL) global cooperative air sampling network (Dlugokencky et al., 2003, 2009), using the same set of global background monitoring sites as Bergamaschi et al. (2009). For computational reasons, the inversion is split into 15-monthly periods with 3 months overlap, using the optimised 3-D fields at the beginning of each year from the previous inversion. We use pre-calculated monthly $\mathrm{OH}$ fields based on Carbon Bond Mechanism 4 (CBM-4) chemistry (Bergamaschi et al., 2009), but do not take into account any potential inter-annual variability of $\mathrm{OH}$ in this study.

\section{Comparison method}

A quantitative comparison of the SCIAMACHY, FTS, and model results is not trivial due to the different averaging kernels influencing the respective absolute amounts of retrieved seasonal variability and annual increase. Therefore, the differing sensitivities of the instruments have to be taken into account appropriately. According to Rodgers (2000) this can be achieved by adjusting the measurements for a common a priori profile eliminating differences attributable to the a priori information. For simplicity, the modelled profiles (CarbonTracker for $\mathrm{XCO}_{2}$ and TM5-4DVAR for $\mathrm{XCH}_{4}$ ) are used as common a priori as in Reuter et al. (2011) enabling direct comparability of SCIAMACHY, FTS, and the corresponding model results:

$c_{\text {adj }}=\hat{c}+\frac{1}{p_{0}} \sum_{l}\left(1-A^{l}\right)\left(x_{\text {mod }}^{l}-x_{\mathrm{a}}^{l}\right) \Delta p^{l}$

In this equation, $\hat{c}$ represents the column-averaged mole fraction retrieved by SCIAMACHY or FTS, $l$ is the index of the vertical layer, $A^{l}$ the column averaging kernel, $x_{\mathrm{a}}^{l}$ the a priori mole fraction, and $x_{\text {mod }}^{l}$ the modelled mole fraction (and new common a priori) of layer $l . \Delta p^{l}$ is the pressure differ- ence between the upper and lower boundary of layer $l$ and $p_{0}$ denotes surface pressure.

The adjustment can be neglected when at least one of the two following conditions is fulfilled: (i) The averaging kernel vector $\boldsymbol{A}$ is close to 1 for all layers or (ii) the a priori profile $\boldsymbol{x}_{a}$ is close to the model profile $\boldsymbol{x}_{\text {mod }}$.

In the case of $\mathrm{XCO}_{2}$, the dynamic FTS a priori profiles changing with time and latitude of the site are close to the corresponding model profiles because the FTS a priori is based on GLOBALVIEW including surface and tower in situ measurements collocated with or near TCCON sites which are also assimilated in CarbonTracker. As a consequence, the adjustment described in Eq. (2) is marginal compared to the precision of SCIAMACHY (see also discussion in Reuter et al., 2011) and is therefore omitted in the following for the sake of simplicity. The same is true for $\mathrm{XCH}_{4}$ because the FTS averaging kernels are close to 1 for typical conditions (Wunch et al., 2011a) and are generally much more uniform compared to SCIAMACHY. In contrast to FTS, neither condition is fulfilled for the WFM-DOAS retrieval algorithm, which uses one static a priori profile globally and therefore the satellite data are adjusted according to Eq. (2) for both analysed species. A typical adjustment of the satellite monthly means is $0.15 \%$ for $\mathrm{XCO}_{2}$ and $0.40 \%$ for $\mathrm{XCH}_{4}$.

\section{Results}

The validation and intercomparison results are shown in Tables 1-3. An additional visualisation for the five sites with the longest temporal overlap of the SCIAMACHY and TCCON data (Park Falls since 2004, Darwin since 2005, Bremen since 2007, Lamont and Wollongong since 2008) can be found in Figs. 1-3. The order of the sites in the Tables and Figures is according to latitude. Tables/Figs. 1 and 3 summarise the results related to the agreement of the monthly means for $\mathrm{XCO}_{2}$ and $\mathrm{XCH}_{4}$, respectively, whereas Table and Fig. 2 show additional comparisons for $\mathrm{XCO}_{2}$ related to the annual increase and the seasonal cycle amplitude.

\subsection{Carbon dioxide}

\subsubsection{Precision, accuracy, and correlation}

The carbon dioxide results are listed for each site separately in Table 1 showing the mean differences $d$ to FTS and CarbonTracker, the standard deviations of the differences $s$ and the correlation coefficients $r$ for the original and scan-anglecorrected SCIAMACHY data. Also shown is the global offset which is the averaged $d$ over all sites, the regional precision relative to the reference which is the averaged $s$, the relative accuracy which is the standard deviation of $d$, and the mean correlation. The corresponding scan-anglecorrected time series are depicted in Fig. 1 for Bremen, Park Falls, Lamont, Darwin, and Wollongong. Overall, we find good agreement between SCIAMACHY and the reference 
Table 1. Validation and comparison results for WFMDv2.1 $\mathrm{XCO}_{2}$ based on monthly data within the time period 2003-2009. Shown are the number of coincident months $n$ of data availability for SCIAMACHY and the comparative data set, the mean difference $d$ to FTS and CarbonTracker, the standard deviation of the difference $s$ and the correlation coefficients $r$ for the analysed sites. Also shown are the corresponding results for the scan-angle-corrected SCIAMACHY data (SCIA ${ }^{\mathrm{C}}$ ), which form the basis of the error characterisation. The global offset is the averaged mean difference, the regional precision relative to the reference is the averaged standard deviation of the difference, and the relative accuracy is the standard deviation of the mean differences.

\begin{tabular}{|c|c|c|c|c|c|}
\hline Location & & SCIA-FTS & SCIA $^{\mathrm{C}}$-FTS & SCIA-CT & SCIA $^{\mathrm{C}}-\mathrm{CT}$ \\
\hline \multirow{4}{*}{$\begin{array}{l}\text { Białystok } \\
\left(53.23^{\circ} \mathrm{N}, 23.02^{\circ} \mathrm{E}\right)\end{array}$} & $n[-]$ & 4 & 4 & 37 & 37 \\
\hline & $d[\mathrm{ppm}]$ & 2.63 & 2.53 & 0.86 & 0.90 \\
\hline & $s[\mathrm{ppm}]$ & 2.40 & 2.03 & 2.08 & 1.96 \\
\hline & $r[-]$ & 0.83 & 0.85 & 0.91 & 0.92 \\
\hline \multirow{4}{*}{$\begin{array}{l}\text { Bremen } \\
\left(53.10^{\circ} \mathrm{N}, 8.85^{\circ} \mathrm{E}\right)\end{array}$} & $n$ & 9 & 9 & 26 & 26 \\
\hline & $d$ & 1.35 & 0.70 & 1.43 & 1.12 \\
\hline & $s$ & 1.27 & 1.17 & 2.52 & 2.33 \\
\hline & $r$ & 0.83 & 0.94 & 0.88 & 0.89 \\
\hline \multirow{4}{*}{$\begin{array}{l}\text { Orléans } \\
\left(47.97^{\circ} \mathrm{N}, 2.11^{\circ} \mathrm{E}\right)\end{array}$} & $n$ & 1 & 1 & 35 & 35 \\
\hline & $d$ & - & - & 0.29 & 0.11 \\
\hline & $s$ & - & - & 1.74 & 1.99 \\
\hline & $r$ & - & - & 0.93 & 0.91 \\
\hline \multirow{4}{*}{$\begin{array}{l}\text { Garmisch } \\
\left(47.48^{\circ} \mathrm{N}, 11.06^{\circ} \mathrm{E}\right)\end{array}$} & $n$ & 5 & 5 & 40 & 40 \\
\hline & $d$ & 1.52 & 0.26 & -0.08 & -0.80 \\
\hline & $s$ & 2.08 & 2.64 & 1.89 & 1.94 \\
\hline & $r$ & 0.56 & 0.20 & 0.93 & 0.93 \\
\hline \multirow{4}{*}{$\begin{array}{l}\text { Park Falls } \\
\left(45.94^{\circ} \mathrm{N}, 90.27^{\circ} \mathrm{W}\right)\end{array}$} & $n$ & 35 & 35 & 43 & 43 \\
\hline & $d$ & 0.44 & -0.12 & -0.78 & -1.24 \\
\hline & $s$ & 2.14 & 1.78 & 2.18 & 1.95 \\
\hline & $r$ & 0.92 & 0.95 & 0.94 & 0.95 \\
\hline \multirow{4}{*}{$\begin{array}{l}\text { Lamont } \\
\left(36.60^{\circ} \mathrm{N}, 97.49^{\circ} \mathrm{W}\right)\end{array}$} & $n$ & 16 & 16 & 71 & 71 \\
\hline & $d$ & -0.94 & -0.80 & -1.80 & -1.61 \\
\hline & $s$ & 2.50 & 1.75 & 2.65 & 1.80 \\
\hline & $r$ & 0.54 & 0.74 & 0.83 & 0.92 \\
\hline \multirow{4}{*}{$\begin{array}{l}\text { Darwin } \\
\left(12.42^{\circ} \mathrm{S}, 130.89^{\circ} \mathrm{E}\right)\end{array}$} & $n$ & 31 & 31 & 50 & 50 \\
\hline & $d$ & 1.88 & 1.87 & 1.73 & 1.70 \\
\hline & $s$ & 4.18 & 3.92 & 4.50 & 4.28 \\
\hline & $r$ & 0.45 & 0.45 & 0.56 & 0.58 \\
\hline \multirow{4}{*}{$\begin{array}{l}\text { Wollongong } \\
\left(34.41^{\circ} \mathrm{S}, 150.88^{\circ} \mathrm{E}\right)\end{array}$} & $n$ & 9 & 9 & 54 & 54 \\
\hline & $d$ & 0.63 & 0.53 & 0.49 & 0.59 \\
\hline & $s$ & 1.12 & 1.54 & 2.05 & 1.55 \\
\hline & $r$ & 0.67 & 0.61 & 0.87 & 0.92 \\
\hline Global Offset & [ppm] & 1.07 & 0.71 & 0.27 & 0.10 \\
\hline Regional Precision & [ppm] & 2.24 & 2.12 & 2.45 & 2.23 \\
\hline Relative Accuracy & [ppm] & 1.15 & 1.14 & 1.16 & 1.20 \\
\hline Mean Correlation & {$[-]$} & 0.69 & 0.68 & 0.86 & 0.88 \\
\hline
\end{tabular}

data with the exception of Darwin with systematic deviations of the seasonal cycle, which can probably be ascribed to a large extent to occurrences of undetected subvisual thin cirrus clouds in the tropics (Schneising et al., 2011).
While the scan angle correction reduces the standard deviations of the satellite data within a given month noticeably by about $1.8 \mathrm{ppm}$ on average (the corresponding standard deviations after the correction are shown as vertical bars in Fig. 1), the effect on the monthly means and the comparison results of Table 1 is typically rather small due to the averaging of 
Table 2. Annual increase and seasonal cycle amplitude at the analysed TCCON sites. The increase is calculated from the unsmoothed data and the amplitudes are derived from smoothed time series as in Fig. 2. The numbers in italic for Darwin show the results of the trend analysis when restricting to 2006-2009 to harmonise the time periods of TCCON and SCIAMACHY/CarbonTracker.

\begin{tabular}{|c|c|c|c|c|c|c|}
\hline \multirow[t]{2}{*}{ Location } & \multicolumn{3}{|c|}{ Annual Increase $\left[\mathrm{ppm} \mathrm{yr}^{-1}\right]$} & \multicolumn{3}{|c|}{ Seasonal Cycle Amplitude [ppm] } \\
\hline & SCIAMACHY & CarbonTracker & TCCON & SCIAMACHY & CarbonTracker & TCCON \\
\hline Białystok & $2.10 \pm 0.19$ & $1.96 \pm 0.04$ & - & $2.9 \pm 0.3$ & $3.3 \pm 0.1$ & - \\
\hline Bremen & $1.92 \pm 0.38$ & $1.96 \pm 0.07$ & - & - & $3.3 \pm 0.1$ & $3.5 \pm 0.2$ \\
\hline Orléans & $1.83 \pm 0.16$ & $1.92 \pm 0.04$ & - & - & $2.8 \pm 0.1$ & - \\
\hline Garmisch & $1.99 \pm 0.15$ & $1.92 \pm 0.03$ & - & $3.2 \pm 0.1$ & $2.8 \pm 0.1$ & - \\
\hline Park Falls & $2.13 \pm 0.15$ & $1.93 \pm 0.03$ & $2.04 \pm 0.08$ & $4.0 \pm 0.3$ & $3.3 \pm 0.1$ & $3.7 \pm 0.3$ \\
\hline Lamont & $2.12 \pm 0.09$ & $1.99 \pm 0.02$ & - & $3.0 \pm 0.2$ & $2.3 \pm 0.1$ & $2.8 \pm 0.2$ \\
\hline $\begin{array}{l}\text { Darwin } \\
\mid 2006-2009\end{array}$ & $\begin{array}{c}1.91 \pm 0.10 \\
2.06 \pm 0.18\end{array}$ & $\begin{array}{c}1.91 \pm 0.01 \\
1.81 \pm 0.01\end{array}$ & $\begin{array}{c}2.34 \pm 0.16 \\
2.34 \pm 0.16\end{array}$ & $3.2 \pm 0.3$ & $0.6 \pm 0.1$ & $0.8 \pm 0.1$ \\
\hline Wollongong & $1.96 \pm 0.08$ & $1.91 \pm 0.02$ & - & $1.2 \pm 0.1$ & $0.4 \pm 0.1$ & $0.6 \pm 0.1$ \\
\hline
\end{tabular}

many measurements. Nevertheless, the corrected data set, which removes the spurious scan angle dependency of the single measurements, is the basis of the following analysis.

The global offset of the satellite data relative to CarbonTracker and TCCON is small amounting to $0.10 \mathrm{ppm}$ and $0.71 \mathrm{ppm}$, respectively. In addition, known global uniform offsets are considered to be unproblematic in inverse modelling and can easily be corrected for prior to flux inversion. A more important error estimate is the relative accuracy explained above quantifying regional biases: it amounts to $1.14 \mathrm{ppm}$ relative to TCCON and $1.20 \mathrm{ppm}$ relative to CarbonTracker. The regional precision of the SCIAMACHY data is about $2.2 \mathrm{ppm}$ relative to both comparative data sets and the mean correlation is 0.88 to CarbonTracker. The somewhat smaller correlation of 0.68 to TCCON is probably due to fewer coincidences of the available monthly data sets at specific sites (e.g., five months for Garmisch). The statistical SCIAMACHY-FTS comparison of Table 1 is not feasible for Orléans because there is only one coincident month in this particular case.

\subsubsection{Annual increase and seasonal cycle}

The annual increases listed in Table 2 are derived by fitting a linear trend to the deseasonalised time series. To this end, we calculate linear trends for month $i \in\{1, \ldots, 12\}$ of the year separately, if data for this month are available for a sufficient number of years. This means that we get up to 12 individual trends (e.g., one for all Januaries) and the annual increase is defined as the mean of these trends plus or minus the corresponding standard error. To ensure comparability, only months which are also available for SCIAMACHY are used to compute the TCCON and CarbonTracker annual increases. For the FTS, estimates are only specified for Park Falls and Darwin because at least three years of data are required to reliably determine the annual increase.
According to Table 2, there are generally no significant differences between the SCIAMACHY and CarbonTracker annual increases. For all sites, the increases agree within their errors with the exception of Park Falls and Lamont where a marginal residual difference remains when taking the standard errors into account. Nevertheless, the global mean increase is somewhat larger for SCIAMACHY than for CarbonTracker $\left(2.00 \pm 0.16 \mathrm{ppm} \mathrm{yr}^{-1}\right.$ compared to $1.94 \pm$ $0.03 \mathrm{ppm} \mathrm{yr}^{-1}$ ). The FTS annual increase at Park Falls also agrees with SCIAMACHY and CarbonTracker within the error bars. However, the FTS increase at Darwin is significantly larger than for the other time series. In this context, it has to be noted that there are limited observational data driving the CarbonTracker assimilation near Darwin and that the TCCON increase might be affected to some extent by a small drift in the FTS measurements at Darwin caused by a gradually changing instrument lineshape between installation in late August 2005 and January 2009 (Houweling et al., 2010). Moreover, it has to be borne in mind that in the case of Darwin a shorter time period is used for the analysis of the TCCON annual increase compared to SCIAMACHY and CarbonTracker. As there are significant inter-annual variations in the trends, the shorter FTS period might also contribute to the differences at Darwin. When restricting the trend analysis to 2006-2009 (numbers in italic in Table 2) to harmonise the time periods the differences between SCIAMACHY and TCCON are no longer significant.

The mean amplitude of the seasonal cycle is obtained by subtracting the linear trend derived above from the time series, smoothing the result using a five-month Hann window (this corresponds to an effective width of 2.5 months) and averaging the resulting amplitudes for all years in which the cycle is reasonably sampled denoting the standard error of the mean as error (see Fig. 2). As can be seen in Table 2, the amplitudes derived from SCIAMACHY are typically larger than those from TCCON which are in turn larger than those from 
Table 3. As Table 1 but for WFMDv2.0.2 $\mathrm{XCH}_{4}$ compared to FTS and TM5-4DVAR. The results are also divided in the two periods before and after the pixel mask change at the beginning of November 2005.

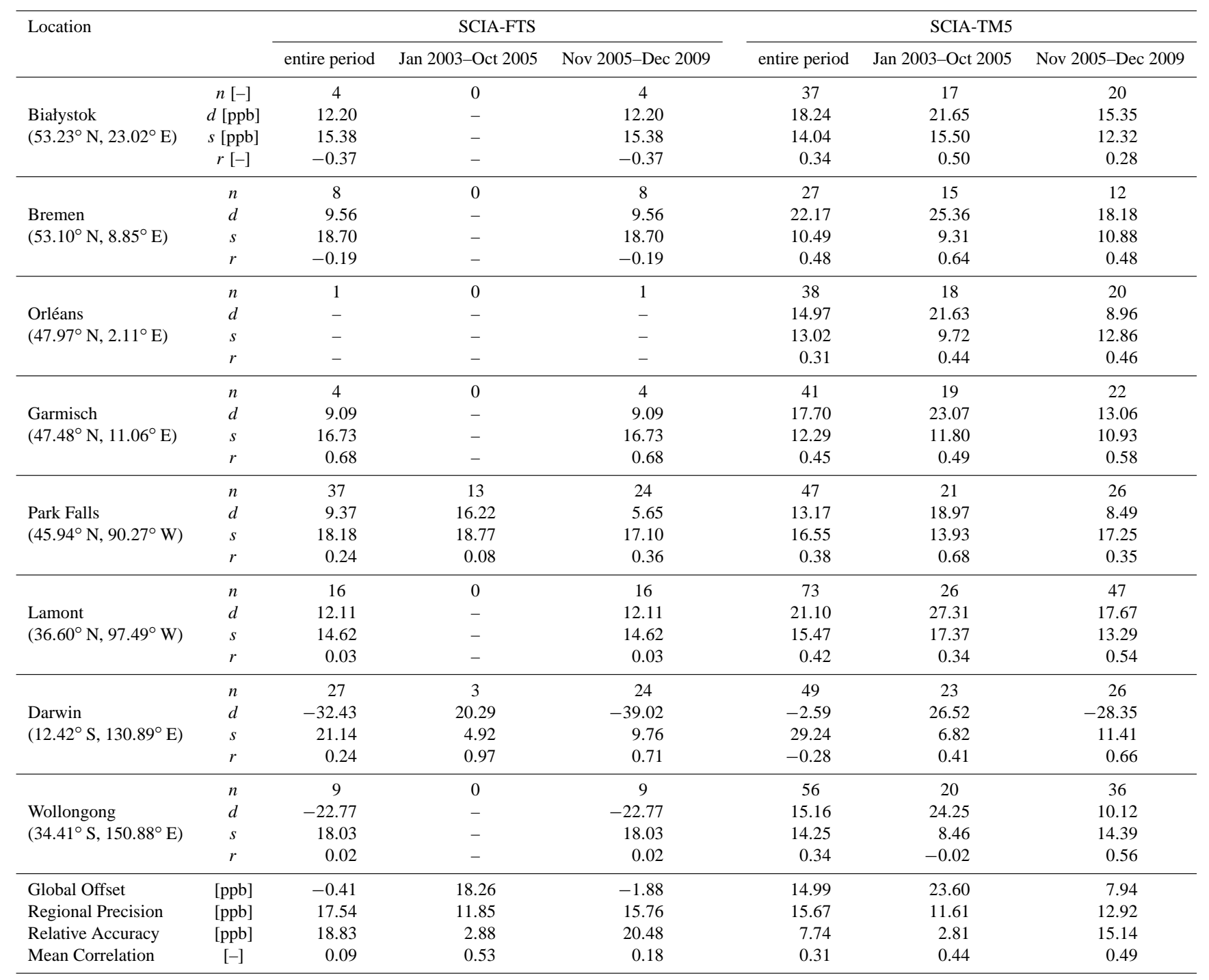

CarbonTracker. However, the differences between the SCIAMACHY and TCCON amplitudes are not significant for the Northern Hemisphere. On the other hand, the differences of northern hemispheric TCCON amplitudes with respect to CarbonTracker can be significant as one sees in the case of Lamont. Potential contributions to the systematic underestimation of seasonal cycle amplitudes in northern temperate latitudes by models compared to TCCON are discussed by Basu et al. (2011). The absolute values of the northern hemispheric TCCON amplitudes are closer to SCIAMACHY than to CarbonTracker, which can be seen from the comparison of those northern hemispheric sites where the amplitudes are available for all three data sets at the same time, namely Park
Falls and Lamont. To get a quantitative impression of the global seasonal cycle differences and their significance we calculate mean amplitudes for sites where estimated seasonal cycle amplitudes are available for all three data sets. Excluding Darwin, where the satellite seasonal cycle seems to be affected by artefacts probably due to variability of undetected subvisual thin cirrus clouds (Schneising et al., 2011), the mean amplitude amounts to $2.7 \pm 0.2 \mathrm{ppm}$ for SCIAMACHY, $2.4 \pm 0.2 \mathrm{ppm}$ for TCCON, and $2.0 \pm 0.1 \mathrm{ppm}$ for CarbonTracker. 

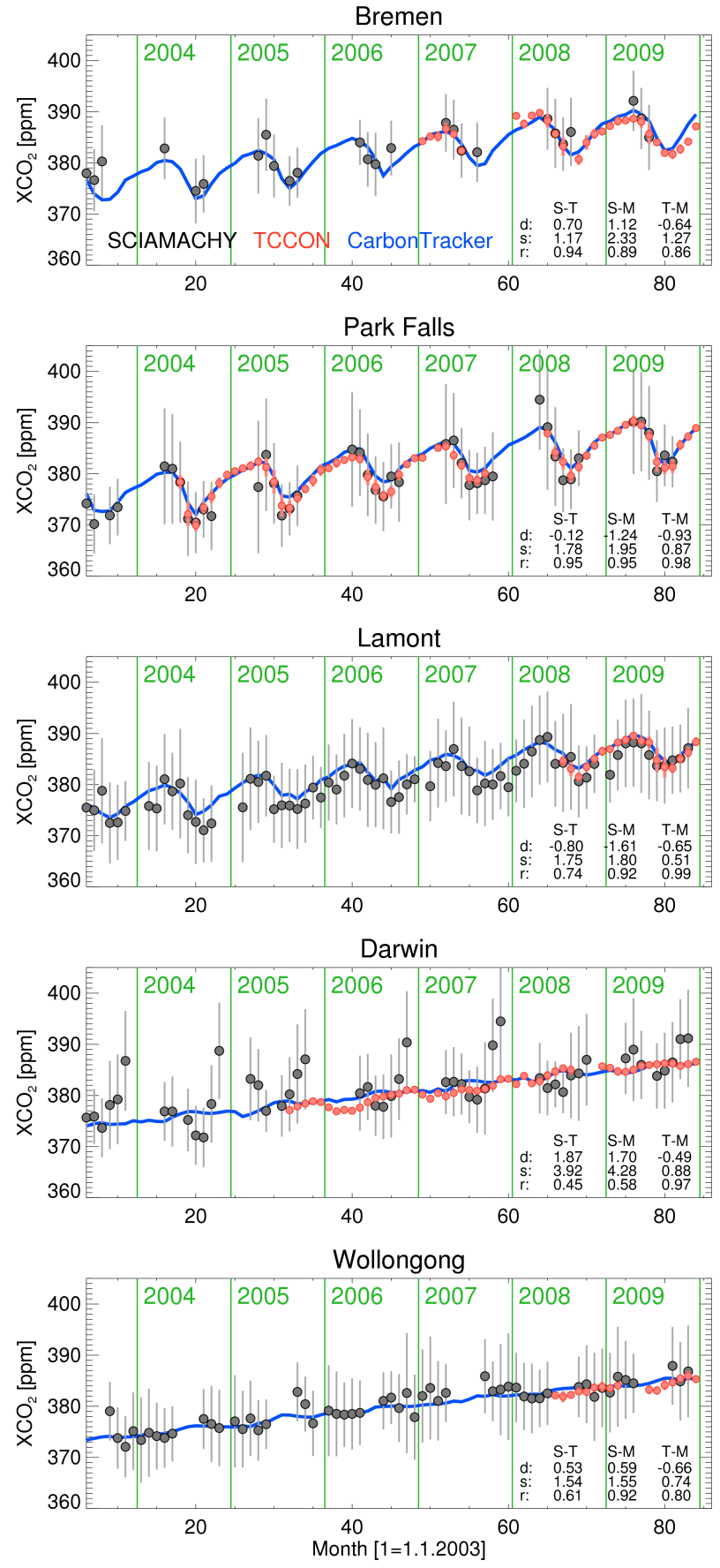

Fig. 1. Intercomparison of the SCIAMACHY WFMDv2.1 $\mathrm{XCO}_{2}$ time series of monthly means (black) with ground based Fourier Transform Spectroscopy (FTS) measurements (red) and CarbonTracker (blue) at selected TCCON sites for the years 2003-2009. The vertical bars correspond to the standard deviations of the data within a given month. The following numbers have been computed based on the monthly averages $(\mathrm{S}=\mathrm{SCIAMACHY}, \mathrm{T}=\mathrm{TCCON}$, $\mathrm{M}=$ Model): $d$ is the absolute mean difference (in ppm), $s$ denotes the standard deviation of the difference (in ppm), and $r$ is the correlation coefficient. The complete results are summarised in Table 1.
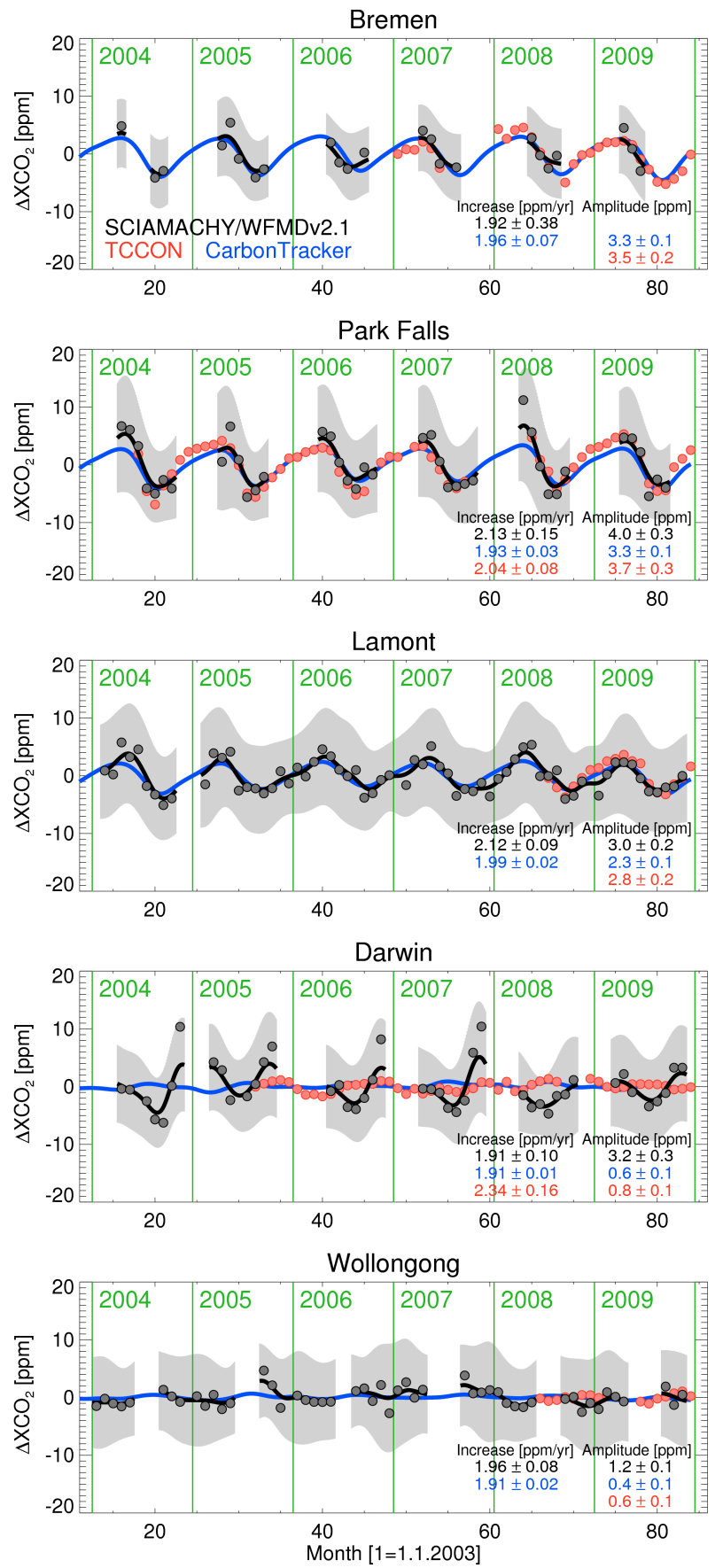

Fig. 2. Carbon dioxide time series with derived linear trends subtracted. The solid lines have been smoothed using a five-month Hann window (which has a similar frequency response to a twoand-a-half-month boxcar filter but better attenuation of high frequencies). The shaded areas represent the standard deviation of the unsmoothed satellite data. The annual increases and the amplitudes of the seasonal cycle are stated for data sets with sufficient data available for computation (e.g., at least three years of data are required to reliably determine the annual increase). The complete results are summarised in Table 2. 

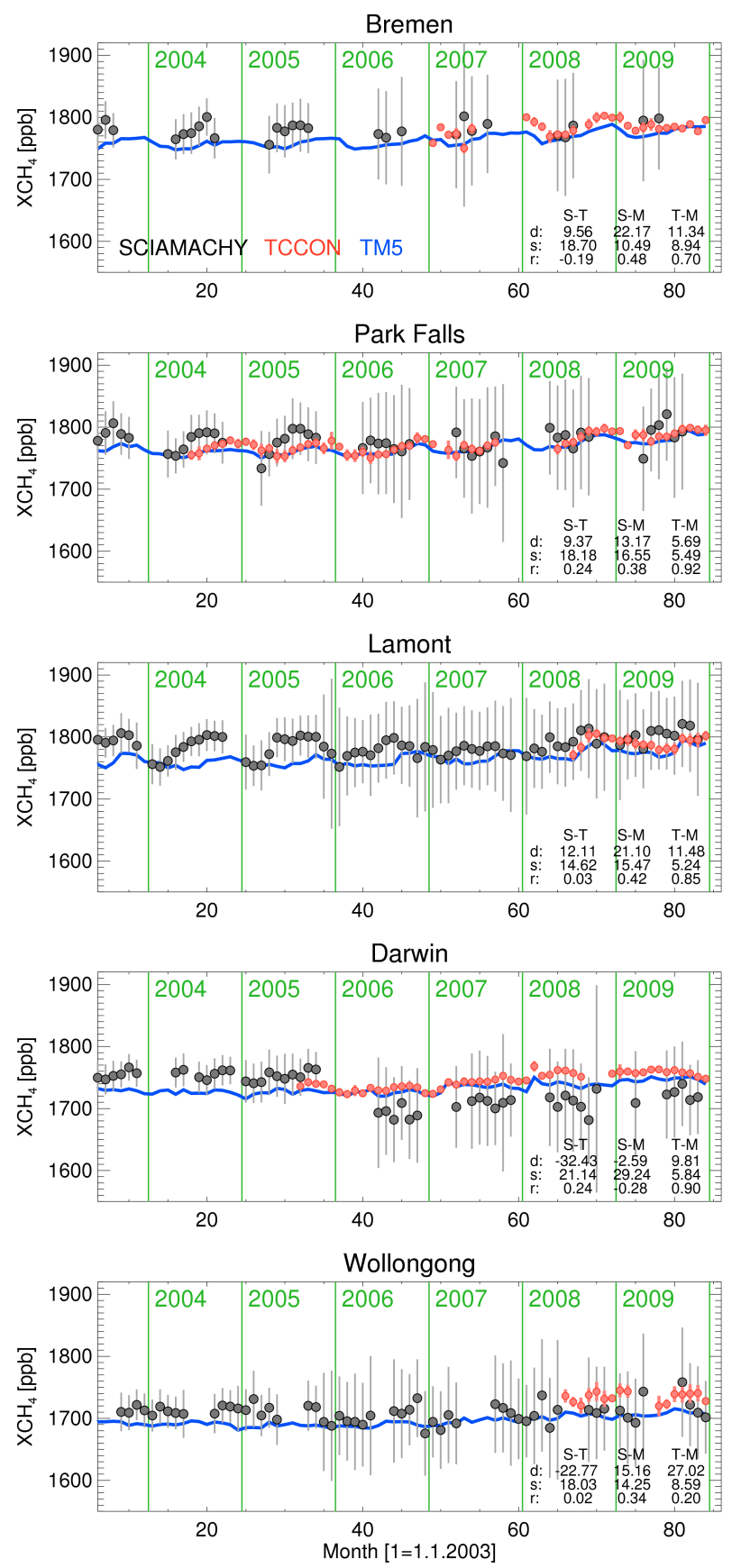

Fig. 3. Intercomparison of the SCIAMACHY WFMDv2.0.2 $\mathrm{XCH}_{4}$ time series of monthly means with ground based Fourier Transform Spectroscopy (FTS) measurements and TM5-4DVAR at selected TCCON sites for the years 2003-2009 as in Fig. 1. The complete results are summarised in Table 3 .

\subsection{Methane}

The methane results are shown in Table 3, which is structured as in the case of carbon dioxide discussed above. SCIAMACHY's channel 6+, which is used for the methane col- umn retrievals, suffers from an increasing number of dead and bad detector pixels including so-called random telegraph detector pixels, which unpredictably jump between at least two quasi-stable dark signal levels (Lichtenberg et al., 2006; Frankenberg et al., 2011; Schneising et al., 2011). As a result, the detector pixel mask had to be altered for time periods after November 2005. Therefore, the results are also divided in the two periods before and after the pixel mask change in addition to the results for the entire time period.

For the entire time period, the relative accuracy quantifying regional biases amounts to $19 \mathrm{ppb}$ relative to TCCON and $8 \mathrm{ppb}$ relative to TM5. The regional precision of the SCIAMACHY data is about $17 \mathrm{ppb}$ relative to both comparative data sets with mean correlations of 0.09 and 0.31 to TCCON and TM5, respectively. As expected from the loss of signal resulting from the loss of detector pixels used in the retrieval, the analysis of the separated time periods confirms that the SCIAMACHY methane data after November 2005 are of reduced quality: the relative accuracy degrades from $3 \mathrm{ppb}$ before to $15 \mathrm{ppb}$ after the pixel mask change when compared with TM5 and from $3 \mathrm{ppb}$ to $20 \mathrm{ppb}$ when compared to TCCON. However, the comparison to TCCON for the first time period is only possible for two sites, namely Park Falls and Darwin, because the other sites were established later than 2005.

The most prominent adverse feature of the SCIAMACHY data in connection with the pixel mask change is the change of the absolute methane levels before and after the alteration in Darwin suggesting a negative tropical bias after November 2005, which is consistent with the findings of Schneising et al. (2011) for latitudinal averages. A possible reason is spectroscopic interference with water vapour, which is highly abundant in the tropics (Frankenberg et al., 2008a; Schneising et al., 2009). The interference is presumably more or less pronounced in the methane fitting window depending on the used detector pixel mask. This potential issue might be resolved in the future by developing a bias correction as a function of water vapour abundance based on external information about collocated water vapour retrieved from SCIAMACHY's spectral measurements in the visible wavelength region (Noël et al., 2004).

\section{Conclusions}

This manuscript presents and discusses the comparison of a global long-term (2003-2009) data set of atmospheric carbon dioxide and methane column-averaged dry air mole fractions retrieved from SCIAMACHY using the scientific retrieval algorithm WFM-DOAS with both ground-based FTS measurements and model results at several TCCON sites providing realistic error estimates of the satellite data.

It is demonstrated that the empirical correction to resolve the dependency of the single $\mathrm{XCO}_{2}$ measurement on the signed scan angle has no significant impact on the validation 
results based on monthly means because many measurements are averaged.

The differences between the SCIAMACHY and CarbonTracker carbon dioxide annual increases are not significant (with typical standard errors in the range of about 0.1$0.2 \mathrm{ppm}$ for SCIAMACHY monthly composite averages). The same is true for the seasonal cycle amplitudes of SCIAMACHY and TCCON on the Northern Hemisphere (standard errors of the order of $0.2-0.3 \mathrm{ppm}$, respectively). However, the differences of northern hemispheric TCCON amplitudes with respect to CarbonTracker are significant for a subset of the analysed sites. In this context, it has to be noted that CarbonTracker exhibits smaller standard errors of the seasonal cycle amplitudes of $0.1 \mathrm{ppm}$ making the detection of significant differences to other data sets easier. Typically, the $\mathrm{XCO}_{2}$ seasonal cycle amplitudes derived from SCIAMACHY are somewhat larger than those from TCCON which are in turn larger than those from CarbonTracker. In general, there is good agreement between the three data sets in the case of carbon dioxide with the exception of Darwin. At this location, the SCIAMACHY seasonal cycle seems to be affected by artefacts, which are attributed to potential retrieval problems in the tropics arising from the fact that undetected clouds are not taken into account in the modelling of the radiative transfer. This is supported by the finding, that the issue at Darwin can be largely resolved by using alternative SCIAMACHY retrievals based on computationally expensive online radiative transfer calculations including selected cloud parameters in the state vector (Reuter et al., 2011).

The regional relative precision of $\mathrm{XCO}_{2}$ is estimated to be about $2.2 \mathrm{ppm}$ and the relative accuracy is $1.1-1.2 \mathrm{ppm}$ for monthly averages within a radius of $500 \mathrm{~km}$. Excluding Darwin, the regional relative precision is $1.9 \mathrm{ppm}$, the relative accuracy is $1.1 \mathrm{ppm}$, and the mean correlation is 0.92 compared to CarbonTracker. These estimates indicate that SCIAMACHY measurements potentially provide valuable information for regional source/sink determination by inverse modelling techniques in places where surface flask observations are sparse at least outside the southern hemispheric tropics.

For $\mathrm{XCH}_{4}$ we derive a regional relative precision of $17 \mathrm{ppb}$ and a relative accuracy of about $10-20$ ppb for monthly averages within the same radius as for carbon dioxide. These estimates are adversely affected by the pixel mask change at the beginning of November 2005, which was necessary because of previous detector degradation in the spectral range used for the methane column retrieval. Therefore, the values are also calculated separately for the two periods before and after the pixel mask change. Before November 2005, the regional relative precision amounts to $12 \mathrm{ppb}$ and the relative accuracy is about $3 \mathrm{ppb}$ as derived by the comparison to TM5. Compared to TCCON, we also calculate values of $12 \mathrm{ppb}$ for the relative precision and about $3 \mathrm{ppb}$ for the relative accuracy, however based on two sites only. This suggests that the SCIAMACHY methane data are suitable for inverse modelling to deduce regional sources and sinks worldwide for this time period.

In conclusion, we have seen that atmospheric greenhouse gas mole fractions retrieved by SCIAMACHY may potentially provide additional information about the carbon cycle when used in inverse modelling at least under specific regional and temporal limitations. This might apply for example to the interaction of vegetation with the atmosphere, because it was shown that the absolute values of the northern hemispheric TCCON amplitudes are closer to SCIAMACHY than to CarbonTracker in all cases where corresponding estimates are available for all data sets at the same time and that the corresponding differences are not significant when compared with SCIAMACHY, whereas they can be significant on a subset of sites when compared with CarbonTracker.

Further improvements can presumably be achieved by evaluating systematic errors with an empirical neuralnetwork-type multivariate regression approach similar to Wunch et al. (2011b) with physically meaningful regression coefficients or by accounting for additional physical parameters in the forward model (e.g., cloud parameters as in Reuter et al., 2010, 2011). Present or future instruments with higher spatial and spectral resolution like GOSAT, OCO-2, or CarbonSat will potentially achieve higher relative accuracy, but SCIAMACHY remains the only satellite instrument measuring the two most important anthropogenic greenhouse gases carbon dioxide and methane with high sensitivity in the boundary layer within the time period 2002-2009. It is yielding a valuable first set of data for the column-averaged dry air mole fractions of carbon dioxide and methane from space and demonstrating the need for accurate retrieval techniques and a proper error characterisation.

Acknowledgements. We thank ESA and DLR for providing us with the SCIAMACHY Level 1 data and the SCIAMACHY calibration team (DLR, SRON, University of Bremen, ESA, and others) for continuously improving the quality of the spectra. TCCON data were obtained from the TCCON Data Archive, operated by the California Institute of Technology from the website at http: //tccon.ipac.caltech.edu/. CarbonTracker 2010 results were provided by NOAA ESRL, Boulder, Colorado, USA from the website at http://carbontracker.noaa.gov.

The research leading to these results has received funding from the ESA project CARBONGASES, which is part of The Changing Earth Science Network, the ESA projects GHG-CCI, ADVANSE, and ALANIS Methane, the European Union's Seventh Framework Programme (FP7/2007-2013) under Grant Agreement no. 218793 and 212095 (MACC and CityZen), the DLR grant SADOS, and from the University and the State of Bremen.

The Park Falls and Lamont TCCON stations are funded by NASA grants NNX11AG01G, NAG5-12247, NNG05-GD07G, and NASA's Orbiting Carbon Observatory Program. We are grateful to the DOE ARM program for technical support in Lamont and Jeff Ayers for technical support in Park Falls. The TCCON sites at Białystok and Orléans are financially supported by the 
Senate of Bremen and the EU projects IMECC and GEOmon. We acknowledge maintenance and logistical work provided by AeroMeteo Service (Białystok) and RAMCES team at LSCE (Gif-sur-Yvette, France).

Edited by: B. N. Duncan

\section{References}

Andrews, A. E., Boering, K. A., Daube, B. C., Wofsy, S. C., Loewenstein, M., Jost, H., Podolske, J. R., Webster, C. R., Herman, R. L., Scott, D. C., Flesch, G. J., Moyer, E. J., Elkins, J. W., Dutton, G. S., Hurst, D. F., Moore, F. L., Ray, E. A., Romashkin, P. A., and Strahan, S. E.: Mean ages of stratospheric air derived from in situ observations of $\mathrm{CO}_{2}, \mathrm{CH}_{4}$, and $\mathrm{N}_{2} \mathrm{O}$, J. Geophys. Res., 106, 32295-32314, doi:10.1029/2001JD000465, 2001.

Barkley, M. P., Frieß, U., and Monks, P. S.: Measuring atmospheric $\mathrm{CO}_{2}$ from space using Full Spectral Initiation (FSI) WFMDOAS, Atmos. Chem. Phys., 6, 3517-3534, doi:10.5194/acp-63517-2006, 2006a.

Barkley, M. P., Monks, P. S., and Engelen, R. J.: Comparison of SCIAMACHY and AIRS $\mathrm{CO}_{2}$ measurements over North America during the summer and autumn of 2003, Geophys. Res. Lett., 33, L20805, doi:10.1029/2006GL026807, 2006b.

Barkley, M. P., Monks, P. S., Frieß, U., Mittermeier, R. L., Fast, H., Körner, S., and Heimann, M.: Comparisons between SCIAMACHY atmospheric $\mathrm{CO}_{2}$ retrieved using (FSI) WFM-DOAS to ground based FTIR data and the TM3 chemistry transport model, Atmos. Chem. Phys., 6, 4483-4498, doi:10.5194/acp-64483-2006, 2006c.

Barkley, M. P., Monks, P. S., Hewitt, A. J., Machida, T., Desai, A., Vinnichenko, N., Nakazawa, T., Yu Arshinov, M., Fedoseev, N., and Watai, T.: Assessing the near surface sensitivity of SCIAMACHY atmospheric $\mathrm{CO}_{2}$ retrieved using (FSI) WFM-DOAS, Atmos. Chem. Phys., 7, 3597-3619, doi:10.5194/acp-7-35972007, 2007.

Basu, S., Houweling, S., Peters, W., Sweeney, C., Machida, T., Maksyutov, S., Patra, P. K., Saito, R., Chevallier, F., Niwa, Y., Matsueda, H., and Sawa, Y.: The seasonal cycle amplitude of total column $\mathrm{CO}_{2}$ : Factors behind the model-observation mismatch, J. Geophys. Res., 116, D23306, doi:10.1029/2011JD016124, 2011.

Bergamaschi, P., Frankenberg, C., Meirink, J. F., Krol, M., Dentener, F., Wagner, T., Platt, U., Kaplan, J. O., Körner, S., Heimann, M., Dlugokencky, E. J., and Goede, A.: Satellite chartography of atmospheric methane from SCIAMACHY onboard ENVISAT: 2. Evaluation based on inverse model simulations, J. Geophys. Res., 112, D02304, doi:10.1029/2006JD007268, 2007.

Bergamaschi, P., Frankenberg, C., Meirink, J. F., Krol, M., Villani, M. G., Houweling, S., Dentener, F., Dlugokencky, E. J., Miller, J. B., Gatti, L. V., Engel, A., and Levin, I.: Inverse modeling of global and regional $\mathrm{CH}_{4}$ emissions using SCIAMACHY satellite retrievals, J. Geophys. Res., 114, D22301, doi:10.1029/2009JD012287, 2009.

Bergamaschi, P., Krol, M., Meirink, J. F., Dentener, F., Segers, A., van Aardenne, J., Monni, S., Vermeulen, A., Schmidt, M., Ra- monet, M., Yver, C., Meinhardt, F., Nisbet, E. G., Fisher, R., O'Doherty, S., and Dlugokencky, E. J.: Inverse modeling of European $\mathrm{CH}_{4}$ emissions 2001-2006, J. Geophys. Res., 115, D22309, doi:10.1029/2010JD014180, 2010.

Bernath, P. F., McElroy, C. T., Abrams, M. C., Boone, C. D., Butler, M., Camy-Peyret, C., Carleer, M., Clerbaux, C., Coheur, P.F., Colin, R., DeCola, C., DeMazière, M., Drummond, J. R., Dufour, D., Evans, W. F. J., Fast, H., Fussen, D., Gilbert, K., Jennings, D. E., Llewellyn, E. J., Lowe, R. P., Mahieu, E., McConnell, J. C., McHugh, M., McLeod, S. D., Michaud, R., Midwinter, C., Nassar, R., Nichitiu, F., Nowlan, C., Rinsland, C. P., Rochon, Y. J., Rowlands, N., Semeniuk, K., Simon, P., Skelton, R., Sloan, J. J., Soucy, M.-A., Strong, K., Tremblay, P., Turnbull, D., Walker, K. A., Walkty, I., Wardle, D. A., Wehrle, V., Zander, R., and Zou, J.: Atmospheric Chemistry Experiment (ACE): Mission overview, Geophys. Res. Lett., 32, L15S01, doi:10.1029/2005GL022386, 2005.

Bloom, A. A., Palmer, P. I., Fraser, A., Reay, D. S., and Frankenberg, C.: Large-scale controls of methanogenesis inferred from methane and gravity spaceborne data, Science, 327, 322-325, doi:10.1126/science.1175176, 2010.

Boesch, H., Baker, D., Connor, B., Crisp, D., and Miller, C.: Global characterization of $\mathrm{CO}_{2}$ column retrievals from shortwave-infrared satellite observations of the Orbiting Carbon Observatory-2 mission, Remote Sens., 2011, 270-304, doi:10.3390/rs3020270, 2011.

Bösch, H., Toon, G. C., Sen, B., Washenfelder, R. A., Wennberg, P. O., Buchwitz, M., de Beek, R., Burrows, J. P., Crisp, D., Christi, M., Connor, B. J., Natraj, V., and Yung, Y. L.: Space-based near-infrared $\mathrm{CO}_{2}$ measurements: testing the Orbiting Carbon Observatory retrieval algorithm and validation concept using SCIAMACHY observations over Park Falls, Wisconsin, J. Geophys. Res., 111, D23302, doi:10.1029/2006JD007080, 2006.

Bousquet, P., Ciais, P., Miller, J. B., Dlugokencky, E. J., Hauglustaine, D. A., Prigent, C., Van der Werf, G. R., Peylin, P., Brunke, E.-G., Carouge, C., Langenfelds, R. L., Lathiere, J., Papa, F., Ramonet, M., Schmidt, M., Steele, L. P., Tyler, S. C., and White, J.: Contribution of anthropogenic and natural sources to atmospheric methane variability, Nature, 443, 439-443, doi:10.1038/nature05132, 2006.

Bovensmann, H., Burrows, J. P., Buchwitz, M., Frerick, J., Noël, S., Rozanov, V. V., Chance, K. V., and Goede, A.: SCIAMACHY mission objectives and measurement modes, J. Atmos. Sci., 56, 127-150, 1999.

Bovensmann, H., Buchwitz, M., Burrows, J. P., Reuter, M., Krings, T., Gerilowski, K., Schneising, O., Heymann, J., Tretner, A., and Erzinger, J.: A remote sensing technique for global monitoring of power plant $\mathrm{CO}_{2}$ emissions from space and related applications, Atmos. Meas. Tech., 3, 781-811, doi:10.5194/amt3-781-2010, 2010.

Buchwitz, M., de Beek, R., Burrows, J. P., Bovensmann, H., Warneke, T., Notholt, J., Meirink, J. F., Goede, A. P. H., Bergamaschi, P., Körner, S., Heimann, M., and Schulz, A.: Atmospheric methane and carbon dioxide from SCIAMACHY satellite data: initial comparison with chemistry and transport models, Atmos. Chem. Phys., 5, 941-962, doi:10.5194/acp-5-941-2005, 2005a.

Buchwitz, M., de Beek, R., Noël, S., Burrows, J. P., Bovensmann, H., Bremer, H., Bergamaschi, P., Körner, S., and Heimann, 
M.: Carbon monoxide, methane and carbon dioxide columns retrieved from SCIAMACHY by WFM-DOAS: year 2003 initial data set, Atmos. Chem. Phys., 5, 3313-3329, doi:10.5194/acp-53313-2005, 2005b.

Buchwitz, M., de Beek, R., Noël, S., Burrows, J. P., Bovensmann, H., Schneising, O., Khlystova, I., Bruns, M., Bremer, H., Bergamaschi, P., Körner, S., and Heimann, M.: Atmospheric carbon gases retrieved from SCIAMACHY by WFM-DOAS: version $0.5 \mathrm{CO}$ and $\mathrm{CH}_{4}$ and impact of calibration improvements on $\mathrm{CO}_{2}$ retrieval, Atmos. Chem. Phys., 6, 2727-2751, doi:10.5194/acp6-2727-2006, 2006.

Buchwitz, M., Schneising, O., Burrows, J. P., Bovensmann, H., Reuter, M., and Notholt, J.: First direct observation of the atmospheric $\mathrm{CO}_{2}$ year-to-year increase from space, Atmos. Chem. Phys., 7, 4249-4256, doi:10.5194/acp-7-4249-2007, 2007.

Burrows, J. P. and Chance, K. V.: Scanning Imaging Absorption Spectrometer for Atmospheric Chartography, Proc. SPIE, 1490, 146-155, doi:10.1117/12.46619, 1991.

Burrows, J. P., Schneider, W., Geary, J. C., Chance, K. V., Goede, A. P. H., Aarts, H. J. M., de Vries, J., Smorenburg, C., and Visser, H.: Atmospheric remote sensing with SCIAMACHY, Digest of Topical Meeting on Optical Remote Sensing of the Atmosphere, Optical Society of America, Washington DC, 4, 7174, 1990.

Burrows, J. P., Hölzle, E., Goede, A. P. H., Visser, H., and Fricke, W.: SCIAMACHY - Scanning Imaging Absorption Spectrometer for Atmospheric Chartography, Acta Astronaut., 35, 445-451, 1995.

Chevallier, F., Bréon, F.-M., and Rayner, P. J.: Contribution of the Orbiting Carbon Observatory to the estimation of $\mathrm{CO}_{2}$ sources and sinks: theoretical study in a variational data assimilation framework, J. Geophys. Res., 112, D09307, doi:10.1029/2006JD007375, 2007.

Crisp, D., Atlas, R. M., Bréon, F.-M., Brown, L. R., Burrows, J. P., Ciais, P., Connor, B. J., Doney, S. C., Fung, I. Y., Jacob, D. J., Miller, C. E., O’Brien, D., Pawson, S., Randerson, J. T., Rayner, P., Salawitch, R. S., Sander, S. P., Sen, B., Stephens, G. L., Tans, P. P., Toon, G. C., Wennberg, P. O., Wofsy, S. C., Yung, Y. L., Kuang, Z., Chudasama, B., Sprague, G., Weiss, P., Pollock, R., Kenyon, D., and Schroll, S.: The Orbiting Carbon Observatory (OCO) mission, Adv. Space Res., 34, 700-709, 2004.

Deutscher, N. M., Griffith, D. W. T., Bryant, G. W., Wennberg, P. O., Toon, G. C., Washenfelder, R. A., Keppel-Aleks, G., Wunch, D., Yavin, Y., Allen, N. T., Blavier, J.-F., Jiménez, R., Daube, B. C., Bright, A. V., Matross, D. M., Wofsy, S. C., and Park, S.: Total column $\mathrm{CO}_{2}$ measurements at Darwin, Australia - site description and calibration against in situ aircraft profiles, Atmos. Meas. Tech., 3, 947-958, doi:10.5194/amt-3-947-2010, 2010.

Dlugokencky, E. J., Houweling, S., Bruhwiler, L., Masarie, K. A., Lang, P. M., Miller, J. B., and Tans, P. P.: Atmospheric methane levels off: Temporary pause or a new steady-state?, Geophys. Res. Lett., 30, 1992, doi:10.1029/2003GL018126, 2003.

Dlugokencky, E. J., Bruhwiler, L., White, J. W. C., Emmons, L. K., Novelli, P. C., Montzka, S. A., Masarie, K. A., Lang, P. M., Crotwell, A. M., Miller, J. B., and Gatti, L. V.: Observational constraints on recent increases in the atmospheric $\mathrm{CH}_{4}$ burden, Geophys. Res. Lett., 36, L18803, doi:10.1029/2009GL039780, 2009.
Frankenberg, C., Meirink, J. F., van Weele, M., Platt, U., and Wagner, T.: Assessing methane emissions from global spaceborne observations, Science, 308, 1010-1014, doi:10.1126/science.1106644, 2005.

Frankenberg, C., Meirink, J. F., Bergamaschi, P., Goede, A. P. H., Heimann, M., Körner, S., Platt, U., van Weele, M., and Wagner, T.: Satellite chartography of atmospheric methane from SCIAMACHY onboard ENVISAT: analysis of the years 2003 and 2004, J. Geophys. Res., 111, D07303, doi:10.1029/2005JD006235, 2006.

Frankenberg, C., Bergamaschi, P., Butz, A., Houweling, S., Meirink, J. F., Notholt, J., Petersen, A. K., Schrijver, H., Warneke, T., and Aben, I.: Tropical methane emissions: a revised view from SCIAMACHY onboard ENVISAT, Geophys. Res. Lett., 35, L15811, doi:10.1029/2008GL034300, 2008a.

Frankenberg, C., Warneke, T., Butz, A., Aben, I., Hase, F., Spietz, P., and Brown, L. R.: Pressure broadening in the $2 v_{3}$ band of methane and its implication on atmospheric retrievals, Atmos. Chem. Phys., 8, 5061-5075, doi:10.5194/acp-8-5061-2008, 2008.

Frankenberg, C., Aben, I., Bergamaschi, P., Dlugokencky, E. J., van Hees, R., Houweling, S., van der Meer, P., Snel, R., and Tol, P.: Global column-averaged methane mixing ratios from 2003 to 2009 as derived from SCIAMACHY: trends and variability, J. Geophys. Res., 116, D04302, doi:10.1029/2010JD014849, 2011.

Heymann, J., Schneising, O., Buchwitz, M., Reuter, M., Rozanov, V. V., Velazco, V. A., Bovensmann, H., and Burrows, J. P.: SCIAMACHY WFM-DOAS $\mathrm{XCO}_{2}$ : Comparison with CarbonTracker focussing on aerosols and clouds, in preparation, 2012.

Houweling, S., Breon, F.-M., Aben, I., Rödenbeck, C., Gloor, M., Heimann, M., and Ciais, P.: Inverse modeling of $\mathrm{CO}_{2}$ sources and sinks using satellite data: a synthetic inter-comparison of measurement techniques and their performance as a function of space and time, Atmos. Chem. Phys., 4, 523-538, doi:10.5194/acp-4-523-2004, 2004.

Houweling, S., Hartmann, W., Aben, I., Schrijver, H., Skidmore, J., Roelofs, G.-J., and Breon, F.-M.: Evidence of systematic errors in SCIAMACHY-observed $\mathrm{CO}_{2}$ due to aerosols, Atmos. Chem. Phys., 5, 3003-3013, doi:10.5194/acp-5-3003-2005, 2005.

Houweling, S., Aben, I., Breon, F.-M., Chevallier, F., Deutscher, N., Engelen, R., Gerbig, C., Griffith, D., Hungershoefer, K., Macatangay, R., Marshall, J., Notholt, J., Peters, W., and Serrar, S.: The importance of transport model uncertainties for the estimation of $\mathrm{CO}_{2}$ sources and sinks using satellite measurements, Atmos. Chem. Phys., 10, 9981-9992, doi:10.5194/acp-10-99812010, 2010.

Krol, M., Houweling, S., Bregman, B., van den Broek, M., Segers, A., van Velthoven, P., Peters, W., Dentener, F., and Bergamaschi, P.: The two-way nested global chemistry-transport zoom model TM5: algorithm and applications, Atmos. Chem. Phys., 5, 417432, doi:10.5194/acp-5-417-2005, 2005.

Lichtenberg, G., Kleipool, Q., Krijger, J. M., van Soest, G., van Hees, R., Tilstra, L. G., Acarreta, J. R., Aben, I., Ahlers, B., Bovensmann, H., Chance, K., Gloudemans, A. M. S., Hoogeveen, R. W. M., Jongma, R. T. N., Noël, S., Piters, A., Schrijver, H., Schrijvers, C., Sioris, C. E., Skupin, J., Slijkhuis, 
S., Stammes, P., and Wuttke, M.: SCIAMACHY Level 1 data: calibration concept and in-flight calibration, Atmos. Chem. Phys., 6, 5347-5367, doi:10.5194/acp-6-5347-2006, 2006.

Meirink, J. F., Bergamaschi, P., and Krol, M. C.: Fourdimensional variational data assimilation for inverse modelling of atmospheric methane emissions: method and comparison with synthesis inversion, Atmos. Chem. Phys., 8, 6341-6353, doi:10.5194/acp-8-6341-2008, 2008.

Messerschmidt, J., Geibel, M. C., Blumenstock, T., Chen, H., Deutscher, N. M., Engel, A., Feist, D. G., Gerbig, C., Gisi, M., Hase, F., Katrynski, K., Kolle, O., Lavrič, J. V., Notholt, J., Palm, M., Ramonet, M., Rettinger, M., Schmidt, M., Sussmann, R., Toon, G. C., Truong, F., Warneke, T., Wennberg, P. O., Wunch, D., and Xueref-Remy, I.: Calibration of TCCON column-averaged $\mathrm{CO}_{2}$ : the first aircraft campaign over European TCCON sites, Atmos. Chem. Phys., 11, 10765-10777, doi:10.5194/acp-11-10765-2011, 2011.

Miller, C. E., Crisp, D., DeCola, P. L., Olsen, S. C., Randerson, J. T., Michalak, A. M., Alkhaled, A., Rayner, P., Jacob, D. J., Suntharalingam, P., Jones, D. B. A., Denning, A. S., Nicholls, M. E., Doney, S. C., Pawson, S., Boesch, H., Connor, B. J., Fung, I. Y., O’Brien, D., Salawitch, R. J., Sander, S. P., Sen, B., Tans, P., Toon, G. C., Wennberg, P. O., Wofsy, S. C., Yung, Y. L., and Law, R. M.: Precision requirements for space-based $\mathrm{X}_{\mathrm{CO}_{2}}$ data, J. Geophys. Res., 112, D10314, doi:10.1029/2006JD007659, 2007.

Noël, S., Buchwitz, M., and Burrows, J. P.: First retrieval of global water vapour column amounts from SCIAMACHY measurements, Atmos. Chem. Phys., 4, 111-125, doi:10.5194/acp-4111-2004, 2004.

Peters, W., Jacobson, A. R., Sweeney, C., Andrews, A. E., Conway, T. J., Masarie, K., Miller, J. B., Bruhwiler, L. M. P., Pétron, G., Hirsch, A. I., Worthy, D. E. J., van der Werf, G. R., Randerson, J. T., Wennberg, P. O., Krol, M. C., and Tans, P. P.: An atmospheric perspective on North American carbon dioxide exchange: CarbonTracker, Proceedings of the National Academy of Sciences (PNAS) of the United States of America, 104, 18925-18930, doi:10.1073/pnas.0708986104, 2007.

Peters, W., Krol, M. C., van der Werf, G. R., Houweling, S., Jones, C. D., Hughes, J., Schaefer, K., Masarie, K. A., Jacobson, A. R., Miller, J. B., Cho, C. H., Ramonet, M., Schmidt, M., Ciattaglia, L., Apadula, F., Heltai, D., Meinhardt, F., di Sarra, A. G., Piacentino, S., Sferlazzo, D., Aalto, T., Hatakka, J., Ström, J., Haszpra, L., Meijer, H. A. J., van der Laan, S., Neubert, R. E. M., Jordan, A., Rodó, X., Morguí, J.A., Vermeulen, A. T., Popa, E., Rozanski, K., Zimnoch, M., Manning, A. C., Leuenberger, M., Uglietti, C., Dolman, A. J., Ciais, P., Heimann, M., and Tans, P. P.: Seven years of recent European net terrestrial carbon dioxide exchange constrained by atmospheric observations, Global Change Biol., 16, 1317-1337, doi:10.1111/j.1365-2486.2009.02078.x, 2010.

Rayner, P. J. and O'Brien, D. M.: The utility of remotely sensed $\mathrm{CO}_{2}$ concentration data in surface inversions, Geophys. Res. Lett., 28, 175-178, 2001.

Reuter, M., Buchwitz, M., Schneising, O., Heymann, J., Bovensmann, H., and Burrows, J. P.: A method for improved SCIAMACHY $\mathrm{CO}_{2}$ retrieval in the presence of optically thin clouds, Atmos. Meas. Tech., 3, 209-232, doi:10.5194/amt-3-209-2010, 2010 .
Reuter, M., Bovensmann, H., Buchwitz, M., Burrows, J. P., Connor, B. J., Deutscher, N. M., Griffith, D. W. T., Heymann, J., Keppel-Aleks, G., Messerschmidt, J., Notholt, J., Petri, C., Robinson, J., Schneising, O., Sherlock, V., Velazco, V., Warneke, T., Wennberg, P. O., and Wunch, D.: Retrieval of atmospheric $\mathrm{CO}_{2}$ with enhanced accuracy and precision from SCIAMACHY: validation with FTS measurements and comparison with model results, J. Geophys. Res., 116, D04301, doi:10.1029/2010JD015047, 2011.

Rigby, M., Prinn, R. G., Fraser, P. J., Simmonds, P. G., Langenfelds, R. L., Huang, J., Cunnold, D. M., Steele, L. P., Krummel, P. B., Weiss, R. F., O'Doherty, S., Salameh, P. K., Wang, H. J., Harth, C. M., Mühle, J., and Porter, L. W.: Renewed growth of atmospheric methane, Geophys. Res. Lett., 35, L22805, doi:10.1029/2008GL036037, 2008.

Rodgers, C. D.: Inverse Methods for Atmospheric Sounding: Theory and Practice, World Scientific Publishing, Singapore, 2000.

Schneising, O., Buchwitz, M., Burrows, J. P., Bovensmann, H., Reuter, M., Notholt, J., Macatangay, R., and Warneke, T.: Three years of greenhouse gas column-averaged dry air mole fractions retrieved from satellite - Part 1: Carbon dioxide, Atmos. Chem. Phys., 8, 3827-3853, doi:10.5194/acp-8-3827-2008, 2008.

Schneising, O., Buchwitz, M., Burrows, J. P., Bovensmann, H., Bergamaschi, P., and Peters, W.: Three years of greenhouse gas column-averaged dry air mole fractions retrieved from satellite - Part 2: Methane, Atmos. Chem. Phys., 9, 443-465, doi:10.5194/acp-9-443-2009, 2009.

Schneising, O., Buchwitz, M., Reuter, M., Heymann, J., Bovensmann, H., and Burrows, J. P.: Long-term analysis of carbon dioxide and methane column-averaged mole fractions retrieved from SCIAMACHY, Atmos. Chem. Phys., 11, 28632880, doi:10.5194/acp-11-2863-2011, 2011.

Solomon, S., Qin, D., Manning, M., Chen, Z., Marquis, M., Averyt, K. B., Tignor, M., and Miller, H. L. (eds.): Climate change 2007: The physical science basis, Contribution of working group I to the Fourth Assessment Report of the Intergovernmental Panel on Climate Change (IPCC), Cambridge University Press, Cambridge, UK, 2007.

Stephens, B. B., Gurney, K. R., Tans, P. P., Sweeney, C., Peters, W., Bruhwiler, L., Ciais, P., Ramonet, M., Bousquet, P., Nakazawa, T., Aoki, S., Machida, T., Inoue, G., Vinnichenko, N., Lloyd, J., Jordan, A., Heimann, M., Shibistova, O., Langenfelds, R. L., Steele, L. P., Francey, R. J., and Denning, A. S.: Weak northern and strong tropical land carbon uptake from vertical profiles of atmospheric $\mathrm{CO}_{2}$, Science, 316, 1732-1735, doi:10.1126/science.1137004, 2007.

Toon, G., Blavier, J.-F., Washenfelder, R., Wunch, D., KeppelAleks, G., Wennberg, P., Connor, B., Sherlock, V., Griffith, D., Deutscher, N., and Notholt, J.: Total Column Carbon Observing Network (TCCON), Hyperspectral Imaging and Sensing of the Environment, OSA Technical Digest (CD) (Optical Society of America), paper JMA3, 2009.

Toon, G. C.: The JPL MkIV interferometer, Opt. Photonics News, 2, 19-21, doi:10.1364/OPN.2.10.000019, 1991.

Washenfelder, R. A., Toon, G. C., Blavier, J.-F., Yang, Z., Allen, N. T., Wennberg, P. O., Vay, S. A., Matross, D. M., and Daube, B. C.: Carbon dioxide column abundances at the Wisconsin Tall Tower site, J. Geophys. Res., 111, D22305, doi:10.1029/2006JD007154, 2006. 
Wunch, D., Toon, G. C., Wennberg, P. O., Wofsy, S. C., Stephens, B. B., Fischer, M. L., Uchino, O., Abshire, J. B., Bernath, P., Biraud, S. C., Blavier, J.-F. L., Boone, C., Bowman, K. P., Browell, E. V., Campos, T., Connor, B. J., Daube, B. C., Deutscher, N. M., Diao, M., Elkins, J. W., Gerbig, C., Gottlieb, E., Griffith, D. W. T., Hurst, D. F., Jiménez, R., Keppel-Aleks, G., Kort, E. A., Macatangay, R., Machida, T., Matsueda, H., Moore, F., Morino, I., Park, S., Robinson, J., Roehl, C. M., Sawa, Y., Sherlock, V., Sweeney, C., Tanaka, T., and Zondlo, M. A.: Calibration of the Total Carbon Column Observing Network using aircraft profile data, Atmos. Meas. Tech., 3, 1351-1362, doi:10.5194/amt-3-1351-2010, 2010.

Wunch, D., Toon, G. C., Blavier, J.-F. L., Washenfelder, R. A., Notholt, J., Connor, B. J., Griffith, D. W. T., Sherlock, V., and Wennberg, P. O.: The Total Carbon Column Observing Network, Phil. Trans. R. Soc. A, 369, 2087-2112, doi:10.1098/rsta.2010.0240, 2011a.
Wunch, D., Wennberg, P. O., Toon, G. C., Connor, B. J., Fisher, B., Osterman, G. B., Frankenberg, C., Mandrake, L., O’Dell, C., Ahonen, P., Biraud, S. C., Castano, R., Cressie, N., Crisp, D., Deutscher, N. M., Eldering, A., Fisher, M. L., Griffith, D. W. T., Gunson, M., Heikkinen, P., Keppel-Aleks, G., Kyrö, E., Lindenmaier, R., Macatangay, R., Mendonca, J., Messerschmidt, J., Miller, C. E., Morino, I., Notholt, J., Oyafuso, F. A., Rettinger, M., Robinson, J., Roehl, C. M., Salawitch, R. J., Sherlock, V., Strong, K., Sussmann, R., Tanaka, T., Thompson, D. R., Uchino, O., Warneke, T., and Wofsy, S. C.: A method for evaluating bias in global measurements of $\mathrm{CO} 2$ total columns from space, Atmos. Chem. Phys., 11, 12317-12337, doi:10.5194/acp11-12317-2011, $2011 \mathrm{~b}$.

Yokota, T., Yoshida, Y., Eguchi, N., Ota, Y., Tanaka, T., Watanabe, H., and Maksyutov, S.: Global concentrations of $\mathrm{CO}_{2}$ and $\mathrm{CH}_{4}$ retrieved from GOSAT: First preliminary results, SOLA, 5, 160-163, doi:10.2151/sola.2009-041, 2009. 